School retention in California was just 78.5 percent in 20I2, with stark inequalities between rich and poor districts, and ethnic communities: 73.2 percent of Latinos and 65.7 percent of Afro-Americans completed school in $20 \mathrm{I} 2$. The quality of community colleges and California State Universities is uneven by locality, and upward transfer rates from the California community colleges and California State Universities, and beyond, are very patchy.

Why has access faltered? Arguably, the culprit has been California's Proposition I3, an extraordinary law which enshrined as a "social" principle the antisocial doctrine that government tax/spend is a violation of individual liberty. The proposition has made it very difficult to increase taxes, and triggered recurring budget crises in California. Proposition $\mathrm{I} 3$ remains in place today and is a major stumbling block of efforts to improve access to high-quality public education.

Since the prolonged recession that began in 2008, California has chopped off one third of state funding for higher education. All levels of institution are turning away qualified applicants, for the first time since I960. Significantly, community colleges no longer provide opportunity for all, forcing many students into the for-profit sector, plagued by low completion rates, and the highest level of average student indebtedness in any sector of American higher education.

\section{Where to From Here?}

Currently, institutions in the University of California system face an impossible choice between steeply hiking tuition, undermining access, or allowing material educational conditions to deteriorate and educational and social inequalities to widen further.

Will rampant individualism and fiscal neoliberalism continue to hold sway over the common good in California? Will public support for public higher education continue to deteriorate? Or will Californians find ways to regenerate public support for common provision and equality of opportunity, recognizing that in the education of each lies the interest of all? If they do resurrect the public mission of the system, their example will again influence the world. Repeal of Proposition I3 would be a good place to start.

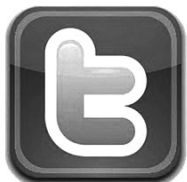

In addition to our Web site and Facebook page, we are now tweeting. We hope you will consider "following" us on Twitter!

\section{Pitfalls of International Cooperative Education Programs in Vietnam}

\section{Thu T. Do}

Thu T. Do is a doctoral student in higher education administration, Saint Louis University, US. E-mail: tdo1o@slu.edu.

\begin{abstract}
A $\mathrm{s}$ a result of globalization, the number of international cooperative education programs between Vietnamese and foreign higher education institutions has been increasing in the last decade. Both involved universities and other organizations appear to achieve their goals; however, the degree of success varies broadly. There are many pitfalls as a result of differences in educational systems and communication among institutions. For various reasons, depending upon the goals and the details of these programs, some languished, some fell apart, and others required further negotiations.
\end{abstract}

\section{International Cooperative Education Programs in VIETNAM}

International cooperative education (ICE) programs are study programs collaboratively offered by Vietnamese and foreign higher education institutions. Students can choose either to complete the whole program in Vietnam or to take part of the coursework in Vietnam and complete the program at the foreign institution. The curriculum includes courses designed by both Vietnamese and foreign institutions. Upon completion of the study program, students are awarded a diploma issued by the foreign institutions.

As of January 20I5, the Ministry of Education and Training (MOET) has approved 266 ICE programs for operation in Vietnam. The top five countries whose higher education institutions offer such programs are France (42 programs), United Kingdom (40), United States (33), Australia (27), and Taiwan (20). Most of these programs are in business- and economics-related fields-such as accounting banking, business administration, finance, information technology, and marketing.

\section{Government Regulations}

The central government in Vietnam acts as the direct supervisor and administrator of higher education. Despite market reforms, Vietnam remains a unitary, nonfederal state in which state power emanates from the National People's Congress, Vietnam's top legislature. The central government determines the management of colleges and universities and educational exchange activities through MOET. MOET is responsible for governing all levels of education 
except for vocational training-which is managed by the Ministry of Labor, Invalids, and Social Affairs. MOET approves all degrees granted by Vietnamese institutions, deciding students' annual enrollment, tuition, and curricula of state-owned institutions. MOET reviews and approves educational exchange programs and develops strategies and policies for foreign invested projects. It also organizes, manages, and examines the quality of foreign cooperative programs and institutions.

In October 20I2, the Vietnamese government issued a decree on Foreign Collaboration and Investment in Education. This decree identifies all regulations regarding educational exchanges, from how to get authorization for operation to the number of Vietnamese students to be taught in one classroom. Regulations and guidance, both from the central government and MOET, establish the framework allowing foreign schools to educate Vietnamese students in partnership with peer Vietnamese higher education institutions - as long as they are granted permission from MOET for academic programs and from the Ministry of Labor, Invalids, and Social Affairs for vocational training programs.

\section{EMERGING ISSUES}

Though cooperative education programs have been implemented in Vietnam since 2000, it was not until October 2012 that the government of Vietnam issued a decree on Foreign Collaboration and Investment in Education to regulate these programs. During 20II-2OI2, the government of Vietnam also established a committee to review the cooperative programs. The review committee found many violations in these programs. Among them was the fact that both parties announced recruitment and application before receiving the approval from MOET. For example, before receiving approval from MOET, Phuong Dong University announced and recruited a number of students to a program in collaboration with Humanagers, a training organization in Australia. Other cooperative education programs have recruited students for a long period without authorization. The case occurred between Vietnamese American Vocational Training College and Broward College, a Florida state college in the United States. This program has recruited and trained more than 700 students since 2007 , without authorization.

Another issue is the quality of the programs and of the foreign institutions. The governmental review committee found that some foreign institutions lacked both a good reputation and good-quality programs. In Vietnam, many consulting centers for students wanting to study abroad now focus on recruiting and reviewing candidates applying for online programs to some foreign institutions. For example, by contacting Orchard Edu Group, a consulting group collaborating with the University of Sunderland,
Thanh Nien Online, a Vietnamese newspaper, reported that the University of Sunderland offers a long-distance master of business administration program and recruits Vietnamese students. Applicants for this program are not required to have a bachelor's degree, but just need five years of work experience to apply. The program takes from six to eight months. Apparently, these centers are not eligible to act as admission committees. It is undeniable that programs like this one are problematic. In the list of foreign institutions that offer programs in Vietnam, it appears that none rank among the top hundred institutions in their home countries. It seems to be difficult to get top-ranked universities to develop programs in Vietnam.

\section{In October 2012, the Vietnamese gov- ernment issued a decree on Foreign Col- laboration and Investment in Education.}

An additional issue of program quality is the high tuition. The difference in tuition between four-year cooperative programs and traditional programs offered by Vietnamese institutions is relatively high. For example, Hanoi University of Science and Technology (HUSTECH) collaborates with Troy University in Alabama (US) to offer cooperative programs. The tuition is $\$$ IO,000 per student enrolling in this program, taking classes in Vietnam, but receiving the degree offered by Troy; in comparison, the tuition fee for a regular four-year program at HUSTECH is \$I,500, which already exceeds the per capita GDP in Vietnam (\$I,4II). One wonders how Vietnamese people can afford the high tuition of cooperative programs. Apparently, wealthy Vietnamese families want their children to receive a foreign degree, because they believe that a degree issued by a foreign institution has more value than a degree issued by a Vietnamese institution. This is why they take the risk of investing a huge amount of money for a degree offered by a foreign institution.

In response to these and other issues, MOET decided to give violating institutions financial fines. MOET also asked these institutions to stop their recruitment and operation, required them to reimburse tuition to their students, and warned not to recognize diplomas graduate students received from these institutions. So far, there have not been legal suits from the institutions or the students against the decisions of MOET; however, there seems to be considerable confusion and ambiguity concerning these joint programs between the Vietnamese government and the institutions involved. 


\section{CONCLUSION}

Vietnam will enjoy a further expansion of international cooperative education programs with foreign countries in the coming decades; however, it is important that collaborating parties recognize the existing issues and seek solutions to the problems. Foreign institutions need to understand the laws and regulations and Vietnamese communication culture. Vietnam needs to establish and review a reliable system for enhancing and measuring the quality of the programs, to avoid having unqualified institutions enter its educational market.

\section{India's Need for Higher Edu- cation Internationalization}

\section{Philip G. Altbach and Eldho Mathews}

Philip G. Altbach is research professor and founding director of the Center for International Higher Education at Boston College. E-mail: altbach@bc.edu. Eldho Mathews is on the staff of the British Council, Chennai, India. E-mail: eldhomathews@gmail.com.

I ndia is on the verge of great power status. The success of 1 the Mars Orbiter Mission is an example. The problem is that India generally does not act like a great power, nor does it have the necessary infrastructures. Let us take one small example-higher education. India dramatically underinvests in its universities and colleges. Most large countries not only have world-class universities but also an effective international higher education "foreign policy"—some call it soft power.

The establishment of Nalanda University and the South Asian University are some small initiatives to develop internationally competitive higher education. But are they enough when compared to India's aspirations to be recognized on par with China's rising global stature?

Higher education internationalization is at the forefront of academic thinking globally. Providing local students with some kind of international consciousness and knowledge is considered important for employment as well as citizenship in a globalizing economy. Educating students from abroad helps by bringing international students to local classrooms. Bringing students from abroad to the country will help future cooperation, economic ties, and the like. Some countries, such as the United Kingdom, the United States, and Australia, earn quite significant sums from educating international students.
Many countries and academic institutions have elaborate strategies for internationalization. The Americans have the Fulbright program, which brings thousands of students and academics to the United States each year-and sends Americans abroad to study and engage in teaching and research. The German Academic Exchange Service offers similar programs. Both China and Japan have national programs to attract foreign students. The Saudi Arabian government sponsors a massive scholarship program to send its students abroad to study.

\section{INDIAN INITIATIVES}

Although institutions like the Indian Council for Cultural Relations offers scholarships to foreign students, its scope is very limited both in terms of numbers and the fields when compared to the programs mentioned earlier. In 20I3-20I4 this council administered only 3,465 scholarships for foreign students to pursue undergraduate, postgraduate, and doctoral programs.

The emergence of the new global environment has been creating tremendous opportunities for internationalization of India. The dramatic expansion in the number of students going abroad and a significant rise in the number of partnerships with foreign institutions are examples of this growth. Apart from this, inward mobility of international students to Indian institutions has also been increasing in recent years, with the majority of the foreign students coming from Asian and African countries. This is mainly because the cost of pursuing higher education and the cost of living in India is very low when compared to other countries.

According to the latest figures available with the Association of Indian Universities, during the year 20I2-20I3 approximately 2I,000 international students were pursuing higher education in I2I institutions in India-compared to the 200,000 Indians studying abroad. Japan and China each host more than I0०,००० international students, and the United States hosts more than 800,000.

Most of India's international students are from South Asia, and regionalization might be a better term than internationalization. The large majority of non-Indian students study in private universities and are hardly represented in the public sector. Manipal University, a private university, stands first with an enrollment of 2,742 international students in 20I2-20I3.

Interestingly, the majority of the Indian public universities seem to be unaware of the potential of attracting short-term study abroad (one semester-in-India/casual studentship) - students from the United States and European countries to their campuses. Currently, only a few central government funded universities-like Jawaharlal Nehru University, Hyderabad University, and the Tata Institute 